\title{
To Study the Efficacy of Reciprocating Single File System and Multifile Rotary Systems in Elimination of Root Canal Bacteria and Endotoxins
}

AIM: To study the efficacy of reciprocating single file system and multifile rotary systems in elimination of root canal bacteria and endotoxins.

MATERIALS AND METHOD: Forty permanent single rooted mandibular premolars with straight canals inoculated with Escherichia Coli suspension for 21 days were selected for the study. Teeth were randomly divided into four groups $(\mathrm{n}=10)$ according to instrumentation system: Group A-Reciproc (VDW); Group B-WaveOne (Dentsply Maillefer); Group C-MTwo (VDW); and Group D-K3( Sybron Endo); Bacterial and endotoxin samples were collected with a sterile paper point before instrumentation and after instrumentation. Culture methods estimated the colony-forming units ( $\mathrm{CFU}$ ) and the Limulus Amebocyte Lysate test was used for quantification of endotoxins. Results so obtained were calculated and statistically analysed.

RESULT: Results before instrumentation concluded that bacteria and endotoxins were found in all of the investigated root canals. After instrumentation all systems were associated with the significant reduction of the bacterial load and endotoxins respectively: Group AReciproc (88.25\% and 89.10\%); Group B- WaveOne (83.53\% and 80.59\%); Group C- MTwo (79.41\% and 75.84\%) and Group D- K3 (67\% and $74.4 \%)$. Statistically no difference was found amongst the instrumentation systems regarding bacteria and endotoxin elimination (P $<0.05$ ).

CONCLUSION: The reciprocating single file, Reciproc and WaveOne were as effective as the multifile rotary systems for the eradication of bacteria and endotoxins from root canals.

KEY WORDS: Endotoxin, Waveone, Reciproc, Colony Forming Unit, Limulus Amebocyte Lysate test.

\section{INTRODUCTION}

Bacteria and their end products mainly endotoxins are responsible factors for causing pulpal and periradicular pathologies. Root canal system is inhabited by different types of microflora but gramnegative bacteria are predominantly responsible for endodontic infections. ${ }^{1}$ Endotoxins are released from outer cell membrane of gram- negative bacteria after multiplication of non-viable bacteria.

Clinical studies conducted at the molecular levels have revealed that although cleaning and shaping significantly decreased the microbial load in canals, various cases still indicated the presence of infection after root canal preparation. ${ }^{2}$

In the past few years, endodontics has flooded with innumerable advancements and technological implementations and applications with the focus of enhancing the prognosis of therapy, increasing the contribution to the preservation as well as increasing the longevity of teeth. ${ }^{3}$ One of the new advancement that standout is rotary instrumentation made of nickel-titanium components, featuring the ability to afford a uniform preparation in less time, thus reducing work fatigue and stress imposition on the patient. ${ }^{4}$

Automated rotary systems are advantageous in comparison to the manual techniques, in terms of rapid and more centred preparations. ${ }^{4}$ These advantages and superiority of rotary systems were still not enough to avoid instrument fatigue and separation rates, a new concept of instrumentation was proposed known as reciprocation ${ }^{5}$, that was based on alternating movement.

LAL test is highly specific and sensitive key available for the detection and measurement of bacterial endotoxins, commonly called as Pyrogen. An enzyme-mediated response to endotoxin causes blood coagulation in Limulus Polyphemus. The rate of reaction depends on amount of endotoxin, the $\mathrm{pH}$ and the temperature. The lysate provides bivalent cations, a proclotting enzyme system and clottable protein required in the reaction. ${ }^{6}$

Therefore, the study aims to evaluate the effectiveness of single file reciprocating systems for 
the elimination of bacteria and endotoxins from root canals in comparison with the multifile rotary systems.

\section{MATERIALS AND METHOD}

Study was conducted in the department of Conservative Dentistry and Endodontics, Bhojia Dental College and Hospital, Baddi (H.P). Approval was granted by Ethical Committee. Forty permanent single rooted mandibular premolars with straight canal were selected for the study.

All teeth were decoronated with sterile diamond discs to maintain standardization $(15 \mathrm{~mm})$. Canal patency was checked by placing \#15 K-file $1 \mathrm{~mm}$ beyond the apical foramen. The teeth were placed in $17 \%$ EDTA followed by $5.25 \%$ Sodium Hypochlorite for 10 minutes each for opening the dentinal tubules for easy penetration of Escherichia Coli. After that, root canals were washed with phosphate buffered saline followed by distilled water to remove residues of the EDTA and Sodium Hypochlorite. All the teeth were autoclaved at $121^{\circ} \mathrm{C}$ and $15 \mathrm{psi}$ for 20 minutes. Culture broth was prepared by inoculating pure culture of Escherichia Coli to freshly prepared sterile BHI broth and followed by incubation at $37^{\circ} \mathrm{C}$ for 24 hours. Before inoculation, canal patency was re-checked with a sterilized \#15 K-file. The samples were inoculated with $10 \mu$ lof the prepared Escherichia Coli suspension BHI broth. The inoculated samples were incubated at $37^{\circ} \mathrm{C}$ for $24-48$ hours.

The infected samples were equally divided into four experimental groups as per the instrumentation technique:-

1. Group A $(\mathbf{n = 1 0})$ : Teeth were prepared with Reciproc file

2. Group B $(\mathbf{n}=\mathbf{1 0})$ : Teeth were prepared with WaveOne file

3. Group C ( $\mathbf{n = 1 0})$ : Teeth were prepared with MTwo file

4. Group D ( $\mathbf{n = 1 0})$ : Teeth were prepared with $\mathrm{K}_{3}$ file.

The first endotoxin sampling was done by placing sterile paper points (size \#15, Dentsply Maillefer) into the full length of the canal and retained in position for 1 minute. Immediately thereafter, the sample was put in pyrogen free vial containing $1 \mathrm{ml}$ of $\mathrm{BHI}$ broth. After the first sampling, the root canals were instrumented according to the group. All instruments were set into permanent rotation with a 6:1 contraangle handpiece (X Smart plus, Dentsply Maillefer) powered by a torque-limited electric circuit . For each MTwo and $\mathrm{K}_{3}$ file systems, individual torque limit and rotational speed programmed in the file library of the motor were used, whereas Reciproc and WaveOne were used in a reciprocating working motion generated by the motor.

Regardless of the technique used, canals were flushed with $0.9 \%$ normal saline solution in between instrumentation and care was taken that a standardized amount of irrigant $(30 \mathrm{ml})$ was used during each canal preparation.

Serial dilutions were made with the sample containing BHI broth from 103-106 and triplicate plating of sample was done to look for $\mathrm{CFU} / \mathrm{ml}$ for bacterial colonies and the $1 \mathrm{ml}$ of sample from each dilution from 103-106 was put in LAL reagent and looked for color change which was assessed by Elisa plate reader at $405 \mathrm{~nm}$. Quantitative estimation of endotoxin was then done using standard graph provided in the LAL kit (Thermofisher Co.).

\section{RESULTS}

The percentage values of bacterial and endotoxin reductions found in all groups tested after instrumentation are shown in Figure 1. Endotoxins were detected in all the samples collected from the root canals. No statistical differences were found in the percentage values of endotoxin reduction obtained between reciprocating systems (Reciproc [89.10\%], WaveOne[80.59\%]) and multifile rotary systems (MTwo [75.84\%] and $\mathrm{K}_{3}$ [74.4\%] $(\mathrm{P}<0.05)$. In the initial samples, bacteria were recovered from all of the tested root canals. Both reciprocating systems: Reciproc [88.75\%]) and WaveOne [83.53\%] and multifile rotary systems: (MTwo $[79.50 \%]$ and $\mathrm{K}_{3}$ [67\%]) showed similar efficacy for eliminating bacterial load $(\mathrm{P}<0.05)$.

\section{DISCUSSION}

The success of endodontic treatment is solely dependent upon complete elimination of microorganisms and their endotoxins from root canal. Induction of inflammation and bone resorption caused by bacteria and endotoxins lead to initiation, propagation and persistence of periradicular lesions. ${ }^{1,7}$ The microbial load within an infected root canal varies from $10^{2}-10^{8}$ according to Sjogren et al., 1991. ${ }^{8}$ Microbes invade all parts of root 


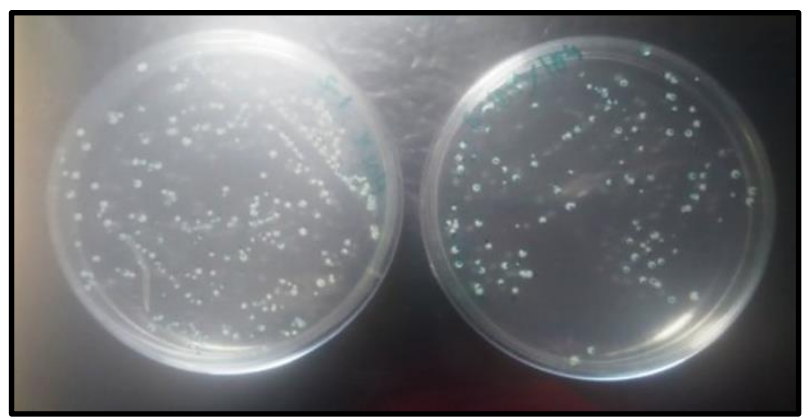

Figure 1. Comparative counts of Colonies of E.coli (CFU/ml.) before and after treatment

\begin{tabular}{|c|c|c|c|c|}
\hline Instrumentation Group & $\begin{array}{c}\text { CFU count after } \\
\text { treatment }\end{array}$ & $\begin{array}{c}\text { Percentage } \\
\text { reduction in } \mathrm{CFU} \\
\text { count }\end{array}$ & $\begin{array}{l}\text { Endotoxin level } \\
\text { after treatment }\end{array}$ & $\begin{array}{c}\text { Percentage } \\
\text { reduction in } \\
\text { Endotoxin level }\end{array}$ \\
\hline Reciproc & $8.50-16$ & $72.93 \%-88.75 \%$ & $13-24.68$ & $78.51 \%-89.10 \%$ \\
\hline WaveOne & $11.3-16$ & $73.56 \%-83.53 \%$ & $24-35$ & $72.93 \%-80.59 \%$ \\
\hline MTwo & $7-22$ & $65.50 \%-79.41 \%$ & $31-39$ & $68.88 \%-75.84 \%$ \\
\hline $\mathrm{K}_{3}$ & $7 \cdot 5-25$ & $44 \cdot 79 \%-67 \%$ & $37-54$ & $58.94 \%-74.4 \%$ \\
\hline
\end{tabular}

Table 1. Mean percentage reduction in CFU count and endotoxin level using different instrumentation techniques

\begin{tabular}{|c|c|c|c|}
\hline S.no & Title & $\begin{array}{c}\text { Chi square } \\
\text { value }\end{array}$ & p value \\
\hline 1. & $\begin{array}{c}\text { Percentage } \\
\text { bacterial } \\
\text { reduction }\end{array}$ & 116.000 & $.430^{*}$ \\
\hline 2. & $\begin{array}{c}\text { Percentage } \\
\text { endotoxin } \\
\text { reduction }\end{array}$ & 85.333 & $.530^{*}$ \\
\hline
\end{tabular}

Table 2. Statistical Analysis ( ${ }^{*} \mathrm{p}<0.05$ significant)

canal system and they are found at depths upto $300 \mu \mathrm{m}$ in dentin which makes their elimination very difficult. ${ }^{9}$ Since last decades endodontics has seen various advancements in terms of technological means focusing on the preservation of natural dentition. ${ }^{10}$

Introduction of NiTi alloy in endodontics in the year 1988 lead to development of rotary systems with the objective of simplicity in addition to reduction in stress levels. ${ }^{11} \mathrm{NiTi}$ instruments are available in different tapers and designs resulting in faster, safer and better quality preparations. Use of multifile system having different tapers results in significant reduction in microbial number but is time consuming process. Recently, single file reciprocating systems have been introduced in dentistry which focuses on root canal preparation with single file only that claims better resistance to instrument separation permitting easier treatment.

The samples were decoronated at the length of 15 $\mathrm{mm}$ from cementoenamel junction to maintain standardization of specimens. The root canals were prepared with \# 25 WaveOne (8\% taper), \# 25 Reciproc (6\% taper), \# $30 \mathrm{~K}_{3}$ (6\% taper) and \#30 MTwo (6\% taper) respectively in crown down technique. Crown down technique was followed because it permits straight line access to apical region, removes coronal interferences and also provides the advantage of deeper penetration of irrigants. $^{12}$

In the present study, the Reciproc and WaveOne files (\#25) were used composed of NiTi alloy known as $\mathrm{M}$-wire made by innovating thermal treatment.13 These two files were compared with $\mathrm{K}_{3}$ NiTi file system which is third generation rotary system (\#25, taper 0.06) and MTwo NiTi rotary system (\#25, taper 
o.06) having taper ranging from 0.06-0.07 which is similar to Reciproc and WaveOne. The chromogenic LAL assay used in the study is preferred for the analysis of endotoxins in root canal infection because of its precision.

Bacterial culture analysis depicted the presence of bacteria in all initial canal samples, with the CFU values per canal ranged from $9 \times 10^{5}-70.8 \times 10^{5}$ which were comparable to the results reported by Xavier et al., 2013 ${ }^{14}$, Martinho et al., $2014^{15}$ and Martinho et al., $2008 .^{16}$ Pre-instrumented samples from the root canal revealed the level of endotoxin ranged from 112.3-173 EUs/ $\mathrm{ml}$ for both in vivo and in vitro studies which is comparable to the studies conducted by Martinho et al., 2014 ${ }^{15}$, Martinho et al. $2010^{17}$ and Xavier et al., 2013.14 The culture analysis revealed significant bacterial reduction in both single file reciprocating instruments i.e Reciproc (88.94\%), WaveOne $(83.09 \%)$ and in multifile system i.e MTwo (75.57\%) and $\mathrm{K}_{3}$ (76\%). Present study showed better bacterial reduction with reciprocating file systems as revealed by Alves et al. ${ }^{19}$ However, no statistical difference was found amongst different files which are comparable to the study conducted by Burklein et al., 2012. ${ }^{18}$ The percentage value of endotoxin reduction achieved between single file Reciproc ( $88.75 \%$ ) and WaveOne (83.57\%) and multifile rotary system MTwo (79.41\%) and $\mathrm{K}_{3}(67 \%)$ showing better elimination with reciprocating systems which were in accordance with the study conducted by Alves et al.,2012 ${ }^{19}$ however no statistical difference was found amongst different files. These findings were similar to the results reported in vitro study conducted by Machado et al., 2010 ${ }^{10}$. Alves et al.,2012 ${ }^{19}$ revealed significant reduction in microbial load by using single file systems.

With regards to the percentage reduction level of endotoxin after instrumentation both single file reciprocating instruments : Reciproc (91.01\%) and WaveOne $(87.75 \%)$, and multifile file systems MTwo $(77.44 \%)$ and $\mathrm{K}_{3}(72.05 \%)$ better reduction in endotoxin levels was shown by reciprocating systems but no statistical difference was found amongst the different files systems used which are in accordance with the study conducted by Martinho et al., 2014. ${ }^{15}$

It is highly important to highlight that the reciprocating instruments considered (WaveOne and Reciproc R25 files) had a tip diameter equivalent to a \#25 K file. Conversely, in the Mtwo and $\mathrm{K}_{3}$ systems, the final instruments used for canal preparation had a tip diameter of \#30 K file. In addition, the WaveOne file 25 has a continuously decreasing taper from the tip to the shaft (o.o. o.65, o.6o, o.55) having different cross-sectional designs over the full length of file, but in the middle part modified triangular convex cross-section with radial lands changes to a neutral rake angle with a triangular convex cross-section near the shaft according to Burklein et al., 2012. ${ }^{18}$

Despite of variations in apical preparation diameter and differences in the design characteristics of the file systems tested in the study, results showed no differences in the median percentage values of bacterial and endotoxin reduction after culture analysis and endotoxin estimation. Moreover, none of the file system completely eliminated bacteria and endotoxin from the root canal.

\section{CONCLUSION}

No file system established root canals free from bacteria and endotoxins. Thus, root canal disinfection should not be concentrated only on a mechanical preparation or on the selection of the instrument sequence, but mechanical preparation of root canal must be assisted by appropriate irrigation protocol leading to successful endodontic treatment.

\section{REFERENCES}

1. Fabricus L, Dahlen G, Holm SE, Mollar AJ. Influence of combinations of oral bacteria on periapical tissues of monkeys. European Journal of Oral Sciences. 1982 Jun;9o(3):200-6.

2. Herrera DR, Silva EJ, Santos CC, Zaia AA, Ferraz CC, Almeida JF, Gomes BP. Root canal content from primary endodontic infection and upregulation of gelatinases in fibroblast cells. International endodontic journal. 2015 Dec;48(12):1168-74.

3. Mounce RE. The $\mathrm{K}_{3}$ rotary nickel-titanium file system. Dental Clinics of North America. 2004 Jan;48(1):137-57.

4. Sanghvi Z, Mistry KU. Design features of rotary instruments in endodontics. The Journal of Ahmedabad Dental College and Hospital. 2011;2(1):6-11.

5. Yared G, Alasmar Ramli G. Single file reciprocation: A literature review. Endodontic Practice Today. 2013 Sep 1;7(3). 
6. Test For Bacterial Endotoxins. Document QAS/11.452 FINAL July 2012.

7. Mollar A, Fabricus L, Dahin G, Ohman A, Heyden

G. Influence on periapical tissues of indigious oral bacteria and necrotic pulp tissues in monkeys. Scand J Dent Res. 1981;89:475-84.

8. Sjögren U, Figdor D, Spångberg L, Sundqvist G. The antimicrobial effect of calcium hydroxide as a short-term intracanal dressing. International endodontic journal. 1991 May;24(3):119-25.

9. Horiba N, Maekawa Y, Matsumoto T, Nakamura $\mathrm{H}$. A study of the distribution of endotoxin in the dentinal wall of infected root canals. Journal of Endodontics. 1990 Jul 1;16(7):331-4.

10. de Lima Machado ME, Sapia LA, Cai S, Martins GH, Nabeshima CK. Comparison of two rotary systems in root canal preparation regarding disinfection. Journal of Endodontics. 2010 Jul 1;36(7):1238-40.

11.Kamatham R. Quick reference guide to rotary endodontic instruments-A comprehensive.

12. Tan BT, Messer HH. The quality of apical canal preparation using hand and rotary instruments with specific criteria for enlargement based on initial apical file size. Journal of Endodontics. 2002 Sep 1;28(9):658-64.

13. Al-Hadlaq SM, AlJarbou FA, AlThumairy RI. Evaluation of cyclic flexural fatigue of M-wire nickeltitanium rotary instruments. Journal of Endodontics. 2010 Feb 1;36(2):305-7.

14. Xavier AC, Martinho FC, Chung A, Oliveira LD, Jorge AO, Valera MC, Carvalho CA. One-visit versus two-visit root canal treatment: effectiveness in the removal of endotoxins and cultivable bacteria. Journal of endodontics. 2013 Aug 1;39(8):959-64.

15. Marihno AC, Martinho FC, Zaia AA, Ferraz CC, Gomes BP. Monitoring the effectiveness of root canal procedures on endotoxin levels found in teeth with chronic apical periodontitis. Journal of applied oral science. 2014 Dec;22(6):490-5.

16. Martinho FC, Gomes BP. Quantification of endotoxins and cultivable bacteria in root canal infection before and after chemomechanical preparation with $2.5 \%$ sodium hypochlorite. Journal of endodontics. 2008 Mar 1;34(3):268-72.

17. Martinho FC, Chiesa WM, Marinho AC, Zaia AA, Ferraz CC, Almeida JF, Souza-Filho FJ, Gomes BP. Clinical investigation of the efficacy of chemomechanical preparation with rotary nickeltitanium files for removal of endotoxin from primarily infected root canals. Journal of endodontics. 2010 Nov 1;36(11):1766-9.

18. Bürklein S, Hinschitza K, Dammaschke T, Schäfer E. Shaping ability and cleaning effectiveness of two single-file systems in severely curved root canals of extracted teeth: Reciproc and WaveOne versus Mtwo and ProTaper. International endodontic journal. 2012 May;45(5):449-61.

19. Alves FR, Rôças IN, Almeida BM, Neves MA, Zoffoli J, Siqueira Jr JF. Quantitative molecular and culture analyses of bacterial elimination in ovalshaped root canals by a single-file instrumentation technique. International endodontic journal. 2012 Sep;45(9):871-7.

Source of support: Nil, Conflict of interest: None declared

\section{AUTHOR AFFILIATIONS:}

1. Professor \& Head

2. Post Graduate Student

3. Professor \& Former Principal

4. Associate Professor

5. Senior Lecturer

Department of Conservative Dentistry and Endodontics, Bhojia Dental College and Hospital, Bhud, Baddi (Himachal Pradesh)

For article enquiry/author contact details, e-mail at: editor.ihri@gmail.com, editor@ihrjournal.com 